\title{
CURRENT SOCIAL WORK IMPOSES NEW CHALLENGES: TWO APPROACHES AND A PARADIGM SHIFT
}

\author{
Kyösti Urponen \\ Lapland University (Finland)
}

\begin{abstract}
The present paper states that social work constitute at same time a political economy and a critical science. The presentation offers some alternative approaches to social work. Current social work faces resource inequality, vital inequality and existential inequality. These inequalities stem from structural and qualitative societal changes due to an aging population, long-term unemployment, globalization, technology developments, production advances, political conflicts as well as to individualization issues in the society. Consequently, social work's old research approaches and practical strategies are now ineffective. Social work faces a crisis and must endure a "paradigm shift" to return to its standard science practice. By means of a new paradigm, it is possible to arrive at a novel type of ontopraxeology, at a different ontological and practical understanding of social work, which per $s e$ is poor in emphasizing personal service along with its ethical and moral aspects. Problems may be simplified and targeted at individuals and families, at the same time when social and individual lives become more complex. Hereafter, social work must perceive itself as an economic factor as well as a societal resource with political characteristics. By solving conflicts and increasing trust, social work increases social capital and furthers equality.

KEY WORDS: social work crisis, social work inequality, social work paradigm shift
\end{abstract}

\begin{abstract}
Anotacija
Straipsnyje pagrindžiama pozicija, kad socialinis darbas aprépia tiek politinès ekonomijos, tiek kritinę teorijas, pateikiami keli alternatyvūs požiūriai ị socialinị darbą. Šiandieniniam socialiniam darbui kyla gyvybiškų poreikių patenkinimo iššūkiais. Jų priežastis - struktūriniai ir kokybiniai visuomenès pokyčiai, vykstantys dèl senejjančios visuomenès, ilgalaikio nedarbo, globalizacijos, technologijų vystymosi, gamybos inovacijų, politinių konfliktų ir individualistinès gyvensenos. Dél to iki šiol taikyti socialinio darbo tyrimų metodai ir praktikos strategijos nebeefektyvios. Socialinis darbas patiria krizę ir turi išgyventi paradigmos pokytį, kad galètų grižti ị ịprastą mokslinès veiklos ritmą. Beieškant naujosios paradigmos dažnai atrandama naujo tipo ontoprakseologija, kitoks socialinio darbo ontologijos ir praktikos suvokimas, kuris sumenkina asmenines paslaugas, kartu ir etinius bei moralinius principus. Problemos tokiu atveju taip pat supaprastinamos ir susiaurinamos iki individo ar šeimos, tuo tarpu socialinis bei asmeninis gyvenimas tampa vis sudėtingesnis. Taigi svarbu, kad socialinis darbas būtų suvokiamas kaip ekonominis veiksnys ir visuomeninis išteklius, turintis politinị atspalvị. Spręsdamas konfliktus ir ugdydamas pasitikèjimą socialinis darbas augina socialinį kapitalą ir didiną visuomenès lygybę.

PAGRINDINIAI ŽODŽIAI: socialinio darbo krizè, nelygybès problema socialiniame darbe, socialinio darbo paradigmos pokytis.
\end{abstract}




\section{Introduction}

Social work is facing some huge challenges and deep crises because of social changes and new types of social problems. Many of the most critical social work researchers easily draw these conclusions as opposed to the difficulties in reaching a consensus and in agreeing on the content and nature of the problems. Today, we can mention and meet many new types of challenges on the rise in social work as follows (Therborn, 2014; Wilkinson and Pickett, 2011):

1. Resource inequality. It exists among an increasing number of traditionally poor people and long-established poverty.

2. Vital inequality. Presently we face a fundamental inequality and completely new forms of poverty; for example, differences in possibilities for life opportunities are at hand. Moreover, people are living in remote communities without services, transport opportunities and information infrastructures. The deteriorating communities are short of positive development possibilities; in addition, special problems as regards refugees, moving labor forces, new types of long term unemployment are at hand

3. Existential inequality. In sight are also existential inequality troubles, increasing problems with human rights and an increasing number of people with societal inclusion problems. Furthermore, we have to cope with many types of discrimination and loss of stable life horizons along with unpredictability for citizens' and immigrants' life spans.

We know that new types of challenges stem from structural and qualitative societal changes in forms of an aging population, long-term unemployment, globalization, technology and production modifications, frequent political conflicts in addition to individualization issues in the society. Social changes along with individualization have problematically impacted the societies in both developed as well as developing countries. Nowadays, we do not remember the wisdom of an African proverb "If you want to travel fast, go alone. But if you want to travel far, let us go together". His means that we have forgotten the principles of collaboration and collective responsibility due to the fact that these issues go against the neo-liberal ideology, which ideology is essentially hostile towards publicly provided social security and social work. The ideology prefers individual and market-based social-problem solutions along with provisions of social services. It does not support the idea of a collective responsibility. The neo-liberal ideology emphases the individual responsibility and reciprocated private help (Barry, 1987). 
Due to dramatically changing in societal contexts it is easy to accept the manifestations of challenges and crises of social work, but it is difficult to reach an agreement and consensus concerning the nature and meaning of the challenges as regards the future of social work (Campanini \& Frost, 2004).

\section{Two alternative approaches are available}

The first approach comprises the line of thinking that the extent and number of problems are on the rise. The other approach concerns the nature and the quality of the changing problems, not only their extent. The solution to the first problem is quite easy and technical. We increase material and immaterial resources attributed to social work for its problem solving. The second approach is more complicated. If we accept the fact that the changes include, not only the growth of their extent, but also qualitative changes, we are facing a paradigm shift along with the situation of crisis science (Kuhn, 1962). This means that we must accept the idea that the society and social work should walk side by side on a linear and continuous way. The problem is that the old research approaches and the practical strategies of social work are not successful and effective in the current societal situations and in the management of issues in social work. This means that social work is in crisis and it must undergo a "paradigm shift" so that it can go back to the normal science practices of social work.

Our problems in social work are not technical; they are more original regarding self-understanding and interpretations of social-work research in addition to practices of social work. Professor of sociology Erik Allardt mentioned once that when societies are subject to deep structural and qualitative changes, the social sciences are obliged to change their approaches and paradigms. (Alestalo \& Haavio-Mannila, 1972).

Fundamentally, social changes and social sciences, like social work, are facing a paradigm shift. During deep and qualitative social changes, the progress of social sciences does not advance in a linear and continuous manner. The status of normal science is possible to arrive at only by correcting prevailing approaches and by finding a new paradigm. The paradigm shift and the loss of status of a normal science bring in ontological and epistemological advances, as well as, self-understanding, together with the comprehension of both the nature of the social reality as well as of the social-work research and practice. By means of the new paradigm, it is possible to arrive at a new type of onto-praxeology, new ontological and practical understanding of social work. 


\section{A paradigm shift as a challenge to social work}

What is wrong with social work? Which are the challenges for social work today? The answers to the questions are troublesome. Nevertheless, it is possible to mention some problems as regards the ontological understanding of the society concerning social work and some failures exhibited by social-work research and practice.

The first problem comprises self-understanding and definitions of social work in the ontopraxeological paradigm of social work. There is a need for critical reflections on the definitions, which build and stand for the paradigm of social-work research and practice. The definitions do not reflect a true picture of the societal nature of social work and its societal impacts. The self-understanding of social work is characterized by a narrow and idealistic picture of the target. Most of the definitions emphasize social work in a one-sided way as an ethical or moral discipline and as a practice in the society. The characterization downgrades or even ignores the political and economic nature of social work.

The second problem consists of the current self-understanding and the definitions of social work. Social work has forgotten and lost its original historical roots and its nature as a critical discipline, which descended from the criticism of the negative effects of the Enlightenment and industrialization. The Enlightenment itself was a critical movement against the traditional Christian world view and its interpretations of social phenomena. Social work and its values criticize the former critic (Cassirer, 2009). This critical background of social work means that its basic nature and character does not represent Christian charity or benevolence. Social work, for instance, is not the same as lay work in churches. Values and ethics of social work are historically rooted in post-Christian value critic and critic of failures in politics of the Enlightenment. Originally, social work was a secular, critical and political movement. The later, nowadays idealistic paradigm or image of social work manifests itself in the fact that social work is only seen as a practical activity, or as a weak or irrational ethical or moral counter-force to neo-liberal politics and economics. However, the sounds of social work have been unvoiced and lack of effective practical influence on the discourse. Social work acts mainly as a critic without disputed contributions and powerful political or economic suggestions. Its arguments are mostly based on ethical and moral considerations (Niiniluoto, 2013).

The idealistic definitions of social work lead to an idealistic policy and practice. Idealism favors a policy which tries to create an integrated good life or direct economic benefits for the society. However, it is very difficult to make a contract concerning a special type of a qualitative social whole. It is easier to create a better 
situation by means of reforms. An incremental and reformist policy is based on critics and critical analysis. An idealistic and a 'good whole' creating approach of social work haves everal times been observed as an irrational way to act. How is it possible to create a totally new community or society without revolution? Social work has also been seen as a mainly cost-triggering activity without direct economic benefits for the society. Many neo-liberal economists and politicians as well as today's social workers scrutinize social work from the economic viewpoint merely in terms of social expenses, not from a social-investment viewpoint. In general terms, social work has been criticized as inefficient, expensive andnon-legitimate and consequently is not supported. Today pure ethical arguments cannot compete with economic ones.

Critics concerning lack of rationality of social work, in turn, stems partly from the fact that social work is not associated with major economic rational features. Social work does not emphasize, for example, market efficiency along with in-put and out-put calculations of production. Social work manages more abstract issues. That is why the same types of calculations - commonly used in economics - are not possible to bring into play in social work. The language of social work is not as mathematical and exact as the language of economics. Social work tries to articulate the language of vulnerable groups, of those alienated and excluded persons. Positive economy-thinkers and politicians consider social work as a kind of ethical-moral manifesto in the society.

\section{Alternative approaches and a new paradigm}

Can we find some alternative approaches and paradigm? Is it possible if we understand that critical science and practice are valuable? Do we then return to the original roots of critical science and social work and apply these ideas in current societal context. Aristotle is an ancient father of critical science. Modern economics and other sciences emphasize that technically applying new knowledge is in itself valuable in an ethical and moral manner. Aristotle understood this issue in a different way. He emphasized that economic and political actions and applications are connected to each other, as well as to certain fundamental ethical and moral requirements. Aristotle created a paradigm which is related to the so called political economy (Aristotele, 2012).

Aristotle outlined political economy as a form of practice-oriented applied social science including ethical and moral elements. To him, the economy as a political economy included both practical science as well as exigency linked to the citizens' daily lives as a cornerstone for good and virtuous life. As a practical applied scien- 
ce, Aristotle introduced two special elements into the political economy: teleological target-orientation and ethical virtue (Sihvola, 1994).

According to Aristotle implementation of activities and targets are not possible, if you do not understand the idea and nature of the concept that you are elaborating. For example, the carpenter cannot build a chair, if he has no idea of the chair. As well as in political and economic social activities the concept for making or reaching the citizens' success is needed. Political economy encounters people's everyday life and its practical problems. Aristotle revealed that the citizens' success is made possible through thriving and virtuous political activities and behavior between people. He also emphasizes meaning of joint political decisions, which are teleological and ethical sensible, in general terms (Simpson, 1998).

Social work includes many features of Aristotle's politics. At the same time it can be a critical social science, its political and economic dimensions are emphasized along with those ethical and moral. This approach perceives the social problems and their solutions not only as ethical but also political and economic. A purely moral approach perceives social issues and problems as more individualrelated than societal. I try to describe some differences between these approaches in the context of social work practice.

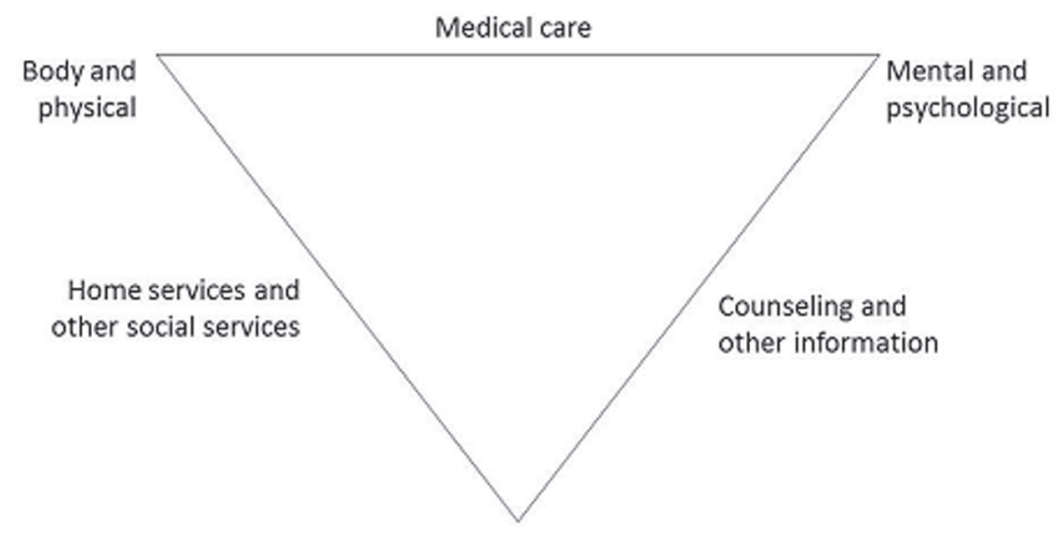

Social arenas

Fig. 1. Social work as an individual and ethical practice but not recognized economic and political discipline (Traditional social service approach)

Today many social problems are individualized. When people cannot join together or integrateinto social arenas or social contacts, the persons have been considered to have physical problems or to lack skills or knowledge. They need home services or institutional care, perhaps some other services and support. If persons 
lack skills or knowledge they need counseling and more information. People with behavioral problems can get social pedagogical teaching and advice for correcting their lifestyle. This approach includes very few political elements. This type of social work is roofed by a special field of administration, followed by legislation, budget recourses and ethical rules. Social work is needed due to individual differences and ethical causes but not because of hard economic or political reasons. This approach does not include real societal critic or demand reforms. This approach is acceptable and justified if the problem is individual without societal dimensions.

But it is also possible to find other type of factors and reasons why citizens cannot attain social arenas or social inclusion and integration. These reasons are more societal than individual. In these cases the former approach is not justified. I'll try to illustrate another approach for social work.

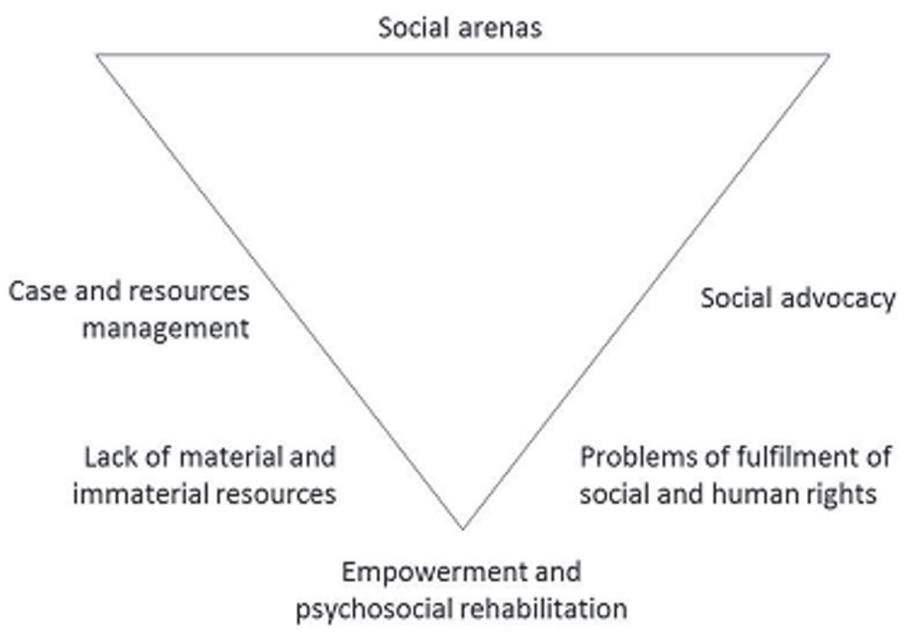

Fig. 2. Social work as a political economic discipline

(Critical advocacy and empowerment approach)

All problems are not individual. Societal issues are often behind problematic life-situations. Sometimes integration to social arenas and activities are not achievable due to lack of material and immaterial resources. In these cases social workers have to be case and resource managers

Nowadays social workers have to play the role of the social advocates, because the social rights of all citizens are not fulfilled. People meet many kinds of discrimination, too high social and physical thresholds, because of wrong planning criteria. People are different and they cannot survive in the same way in all social 
and physical surroundings. When people live for a long time without necessary resources and fulfilled social rights they become alienated and frustrated. In these situations they need psycho- social rehabilitation for empowerment. When social work solves these kinds of problems, it acts in a role of political economy. Social work does not only solve problems for individual citizens, it solves problems for the society, too.

Social work acts politically because it demands changes and reforms in structures and functions of the society. It plays an economic role by solving problems and thereby increases social capital, which is needed besides capital and human capital as a resource of societal progress. At the same time social work saves money because its functions are preventive. Unresolved problems are very expensive. In the sciences, there is a law of indestructibility of matter. In the social work, we meet a law of indestructibility of costs. Costs of unresolved problems accumulate and transfer from one place to another. I give one example from young people's everyday world.

In the compulsory or in the vocational school a young person exhibits school problems and begins to disturb. Teachers get tired of the situation and ask the principal to restore the peace by relegating the student from the school. At the same time access to labor market conditions become poorer. The improved atmosphere in the school generates over time costs for labor market authorities. The unemployed young person can find friends who submit to any activity to pass time. Substance use leads to substance abuse treatment or mental health services, and so forth, where cost arises. Doors are closing in front of the young person. The labor authorities may find that the young is not fit for the labor market. Labor-market costs decrease and change to unemployment benefits. Cost can eventually be transferred and income security regulated by means of subsidies. This young person is not satisfied with social worker's proposals and his level of personal income. $\mathrm{He}$ begins to improve his financial situation by committing offences. Sometimes girls may start sex work. Again the costs are transferred to police, judiciary, prisons or some other authorities.

\section{Conclusions}

I started the article by moving forwards from criticism of the current socialwork paradigm. Solely social work is not enough to underline and emphasize personal services and its ethical and moral aspects. Individualized approaches require citizens to change themselves and to adapt to new situations. Problems may be simplified and targeted at individuals and families, simultaneously when social and individual life turns along with the society out to be more complicated. In 
other words, social work has to perceive itself as an economic factor and a societal resource with political characteristics.

Social work can be at the same time a political economy and a critical science. Aristotle's practical and ethical political economy highlights that the real nature of the citizen is 'zoon politicon'. This means that the citizens are not determined and regulated by economy and its 'invisible hand' as neo-liberal economists teach. Economy is not value free and without political connotations. Aristotle's political economy is openly linked to values. People on the grass root level gather to communities and foster a spirit of togetherness when they try to create a virtuous and good life. By solving conflicts and increasing trust, social work increases social capital and furthers equality. Social work as a political science emphasizes that we need the visible hand of ethics' and morals' when we focus on activities in forms of resolving individual problems which problems are at the same time those of the society. As a political economy, social work functions as a life politics along with visible ethics and morality by regulating invisible hand of economics. Ethical and moral principles are needed because of market disruptions. Well-being and good life is not just an economic formation along with its criteria.

\section{References}

Alestalo, M., Haavio-Mannila, E. (1972). Suomalaisen sosiologian juuret. Porvoo, Helsinki: WSOY. Aristoteles. (2012). Politiikka. (Teokset VIII). Helsinki: Gaudeamus.

Barry, N. (1987). On Classical Liberalism and Libertarism. New York: St. Martins Press.

Campanini, A., Frost, E. (eds.). (2004). European Social Work. Rome: Carocci.

Cassirer, E. (2009). Philosophy of the Enlightenment. Princeton: Princeton University Press.

Kraut, R. (2002). Aristotele. Political Philosophy. Oxford: Oxford University Press.

Kuhn, T. S. (1962). The Scientific revolution. Chicago.

Niiniluoto, I. (toim.) (2013). Talous ja filosofia. Helsinki: Gaudeamus.

Shera, W., Wells, L. M. (eds.). (1999). Empowerment Practice in Social Work. Toronto: Canadian Scholars Press. Sihvola, J. (1994). Hyvän elämän politiikka. Näkökulmia Aristoteleen poliittiseen historiaan. Tutkijaliitto.

Simpson, P. L. (1998). A Philosophical Commentary on the Political Philosophy of Aristotele. Chapell Hill: The University of North Carolina Press.

Therborn, G. (2014). Eriarvoisuus tappaa. Tampere: Vastapaino.

Wilkinson, R., Pickett, K. (2011). Tasa-arvo ja hyvinvointi; miksi pienet tuloerot koituvat kaikkien hyväksi? Juva: HS Kirjat. Bookwell. 
